\title{
Optimasi Multiple Can-Order Level pada Can- Order Policy Menggunakan Algoritma Simulated Annealing (Studi Kasus: Spare Part Inventory PT X)
}

\author{
Faldy Maulana Yuantoro dan Budi Santosa \\ Departemen Teknik Industri, Fakultas Teknologi Industri, Institut Teknologi Sepuluh Nopember (ITS) \\ e-mail:budi_s@ie.its.ac.id
}

\begin{abstract}
Abstrak-Persediaan merupakan stok dari barang-barang yang disimpan dan akan digunakan di masa yang akan datang. Salah satu permasalahan yang terjadi adalah apabila permintaan pada suatu item tergolong permintaan yang intermittent. Kebijakan persediaan pada jenis permintaan tersebut sulit untuk ditentukan karena pola pemintaan yang tidak pasti sehingga tingkat kesalahan prediksinya besar. Permasalahan jenis permintaan tersebut muncul pada kebutuhan spare part di PT X yang merupakan perusahaan peleburan aluminium. Untuk mengatasinya, model kebijakan can order policy menggunakan multiple can-order level $\left(\mathrm{s}_{\mathrm{i}}, \mathrm{c}_{\mathrm{ij}}\right.$, $\mathrm{S}_{\mathrm{ij}}$ ) dapat menyelesaikan permasalahan dengan joint replenishment untuk mengkoordinasikan pesanan antar item. Model tersebut diketahui merupakan integer non-linear programming (INLP) yang dapat digolongkan ke dalam permasalahan NP-Hard. Pendekatan metaheuristik yaitu simulated annealing akan digunakan untuk mendapatkan solusi yang memuaskan dengan waktu penyelesaian yang cepat. Metode Global Criterion juga akan digunakan untuk mendapatkan fungsi multi objective, yaitu meminimasi total biaya persediaan dan meminimasi jumlah carrier supplier. Berdasarkan eksperimen dengan 3 supplier dam 157 item didapatkan hasil yang lebih baik dari kebijakan persediaan di PT X dengan adanya penghematan dari kondisi eksisting yang diterapkan perusahaan sebesar $2,6 \%$ pada jumlah carrier dan penghematan biaya sebesar $14,43 \%$ atau sebesar $\$ 81.570,79$ (Rp 1.060.420.270).
\end{abstract}

Kata Kunci-Can Order Policy, Metaheuristik, Multiple CanOrder Level, Simulated Annealing, Spare Part.

\section{PENDAHULUAN}

$\mathrm{P}$ ENGENDALIAN persediaan yang dilakukan secara efektif dapat berperan sangat penting dalam hubungannya dengan supply chain management. Pengendalian inventory dilakukan dengan menentukan apa yang dipesan, berapa jumlah pesanan, dan kapan pemesanan dilakukan. Umumnya, pengendalian inventory digunakan untuk mengurangi adanya investasi, seperti biaya simpan, biaya pemesanan, dan biaya pembelian, dan juga untuk meningkatkan customer service level dengan menghindari adanya shortage.

Strategi penentuan pengendalian inventory ini salah satunya didasarkan pada klasifikasikan tipe permintaan yang berbeda. Permintaan dibagi berdasarkan 4 kategori, antara lain smooth, erratic, intermittent, dan lumpy [1]. Permasalahan yang terjadi pada jenis permintaan yang intermittent adalah sulitnya dalam menentukan strategi kebijakan persediaan karena pola pemintaan yang tidak pasti dan sulit untuk diprediksi.

Permasalahan jenis permintaan tersebut juga muncul pada kebutuhan spare part di PT X. PT X merupakan salah satu pabrik peleburan aluminium di Indonesia. Untuk menjaga keadalan dari peralatan produksi tersebut, perusahaan melakukan strategi maintenance. Untuk melakukan preventive maintenance, dibutuhkan adanya spare part, yang mana spare part tersebut merupakan komponenkomponen pendukung dari mesin-mesin produksi. Saat spare part tersebut tidak tersedia, proses maintenance yang seharusnya dilakukan, menjadi tidak dapat dilakukan sampai spare part dari mesin tersebut tersedia. Hal ini dapat mengakibatkan berhentinya proses produksi, yang mengakibatkan demand dari customer tidak bisa terpenuhi. Hal tersebut menunjukkan bahwa pentingnya pengendalian inventory pada spare part. PT X mengendalikan spare part inventory sebanyak kurang lebih 14.000 jenis item.

Dari mechanical part yang dibutuhkan pada 2018, 61\% diantaranya tergolong ke dalam permintaan intermittent. Prediksi permintaan spare part yang intermittent tersebut yang selalu sulit untuk ditentukan berapa jumlah part di dalam proses maintenance. Selain itu, pemesanan spare part yang dilakukan secara independen pada PT X menyebabkan tingginya ordering cost. Padahal, proses tender pada spare part tidak terlalu signifikan berpengaruh, karena harus melakukan pembelian item yang banyak jenisnya dan penawaran dilihat berdasarkan kesesuaian spesifikasi part. Sehingga, perlu dilakukan kebijakan inventory yang efektif agar biaya inventory tetap rendah, dan jumlah item yang stockout juga rendah.

Seperti yang dikemukakan Ghorbel [2], untuk mengatasi adanya variasi pada suplai kuantitas dan periode yang bervariasi, maka digunakan replenishment policies jenis (s, $\mathrm{S})$. Pada multi-item inventory control, joint replenishment problem (JRP) dapat mengoordinasikan jumlah kuantitas pesanan pada sejumlah item dalam satu gudang [3]. Ketika ada beberapa item yang dipesan pada supplier yang sama, biaya pemesanan akan bergantung pada jumlah pesanan dan jumlah item yang dipesan. Walaupun begitu, jumlah pesanan dari item yang berbeda adalah independen walaupun memiliki supplier yang sama. Untuk mengatasinya, Canorder Policy, yang merupakan pengembangan dari kebijakan (s, S), dapat mengendalikan koordinasi pesanan yang mengakomodasi keterkaitan antar item [4] dan memiliki hasil yang lebih baik dari uncoordinated policy dengan menghasilkan 20\% saving [5]. Can-order policy dilakukan dengan menentukan 3 parameter (s, c, S), yaitu re-order level (s), can-order level (c), dan order-up-to level (S). 
Pada formulasi model yang dibangun oleh Nagasawa \& Irohara [3], model kebijakan (s, c, S) diketahui merupakan integer non-linear programming (INLP). Sehingga, permasalahan seperti ini digolongkan pada permasalahan NP-Hard. Sehingga, jika diselesaikan dengan metode eksak, akan membutuhkan waktu penyelesaian yang sangat lama karena item yang ditangani pada spare part inventory mencapai ratusan sampai ribuan item. Pendekatan metaheuristik akan digunakan untuk mendapatkan solusi yang memuaskan dengan waktu penyelesaian yang cepat. Nagasawa \& Irohara [3] menyelesaikan permasalahan tersebut menggunakan Genetic Algorithm. Jika GA digunakan pada spare part inventory yang memiliki ribuan jenis item, waktu penyelesaian setiap iterasi dapat menjadi lama karena solusi dibangun berdasarkan populasi.

Oleh karena itu, penulis membangun model multi objective multiple can order policy menggunakan Simulated Annealling, agar diharapkan waktu penyelesaiannya lebih. Metode Global Criterion juga akan digunakan untuk mendapatkan fungsi multi objective yang mempertimbangkan fungsi tujuan berdasarkan selisihnya dengan solusi optimal. Fungsi tujuan dari model yang dikembangkan adalah untuk meminimasi total biaya persediaan dan meminimasi jumlah carrier supplier dengan memperhatikan kapasitas penyimpanan dan multiple canorder level untuk mengkoordinasikan item yang memiliki supplier yang sama.

\section{LANDASAN TEORI}

\section{A. Can Order Policy}

Can-order policy atau (s, c, S) policy adalah salah satu tipe dari joint replenishment policy. Balintfy [5] menunjukkan bahwa can-order policy setidaknya lebih baik dari pada replenishment policy terkoordinasi lainnya. Can order policy (sistem s, c, S) digunakan untuk mengendalikan item - item yang terkoordinasi dengan menggunakan 3 parameter, yaitu order-up-to level (S), can-order level (c), dan must-order level atau re-order level (s). Ketika level persediaan dari suatu item berada dibawah $s$, pesanan ditempatkan pada level persediaan item tersebut mencapai $S$. Untuk item lain yang level persediannya dibawah $c$, maka pesanan akan ditempatkan pada level persediaan mencapai $S$. Berikut merupakan gambaran dari persediaan menggunakan can order policy.
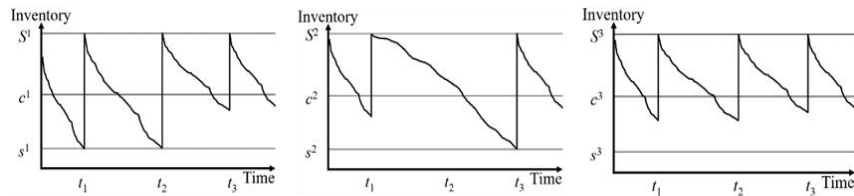

Gambar 1. Sistem Can-Order Policy pada 3 item.

\section{B. Multiple Can-order Level pada Can-order Policy}

Multiple can-order level pada kebijakan can-order diusulkan pertama kali oleh Nagasawa dan Irohara pada tahun 2016. Nagasawa [3] mengadopsi model pada ordering policy yang mempertimbangkan adanya korelasi item. Correlated demand merupakan adanya pengaruh dari permintaan dari 2 atau lebih item pada sekali pembelian dengan probabilitas tinggi. Dari model can-order policy, perubahan dilakukan pada can-order level dan order-up-to level bergantung pada ordering trigger item.

Pada model Nagasawa [3], untuk setiap item i, ordering policy yang dilakukan berupa $\left(\mathrm{s}_{\mathrm{i}}, \mathrm{c}_{\mathrm{ij}}, \mathrm{S}_{\mathrm{ij}}\right)$. Ketika inventory level dari item $i$ berada pada re-order level $s_{i}$, hal tersebut akan memicu replenishment order yang menaikkan level persediaan item i mencapai order-up-to level dari item tersebut $S_{i i}$. Pada waktu yang sama, jika level persediaan dari item $k$ lainnya berada dibawah atau tepat pada canorder level ketika item $i$ berada pada re-order level, lalu can-order level-nya disebut sebagai $c_{i k}$. Item $k$ dimasukkan kedalam tambahan pesanan mencapai order-up-to level untuk item $I, \mathrm{~S}_{\mathrm{ik}}$. Berikut merupakan gambaran can-order policy dengan multiple can-order level.
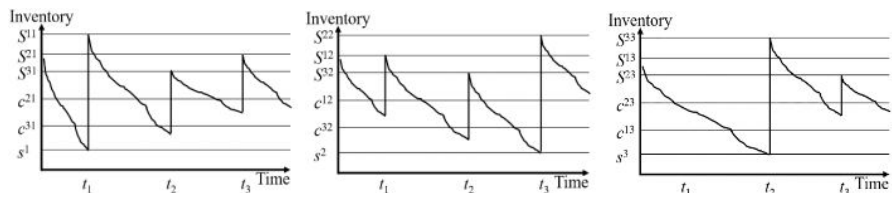

Gambar 2. Multiple Can-order Level pada Sistem (s, c, S) untuk 3 item yang berkorelasi

\section{Algoritma Simulated Annealing}

Metaheuristik merupakan metoda untuk mencari solusi yang memadukan interaksi antara prosedur pencarian lokal dan strategi yang lebih tinggi untuk menciptakan proses yang mampu keluar dari lokal optimal [9]. Salah satu metode pada metaheuristik yang meniru peroses fisik adalah Simulated Annealing (SA). Algoritma SA pertama kali ditemukan oleh Metropolis, Rosenbluth dan Teller pada tahun 1953 untuk menyimulasikan proses pendinginan material dalam heat bath. Annealing adalah satu teknik yang dikenal dalam bidang metalurgi, digunakan dalam mempelajari proses pembentukan kristal dalam suatu materi [9]. Distribusi probabilitas Boltzmann ini digunakan sebagai acuan untuk menerima terlebih dahulu solusi yang lebih buruk atau tidak sehingga dapat menghindari jebakan local optima.

\section{Metode Global Kriteria}

Optimasi multi-tujuan merupakan persoalan optimasi yang memiliki lebih dari satu fungsi tujuan, yang memungkinkan terjadi konflik antar fungsi tujuan tersebut [9]. Global kriteria merupakan salah satu dari pendekatan $a$ priori yang menjelaskan teknik untuk permasalahan fungsi tujuan dengan menjadikannya sebagai fungsi tunggal. Tujuannya adalah untuk mengukur seberapa dekat pengambil keputusan dapat menentukan solusi optimal Fungsi multi objective yang digunakan pada global kriteria, adalah sebagai berikut [10].

$$
\operatorname{Min} \quad F=\sum_{l=1}^{K}\left[\frac{f_{l}\left(x^{*}\right)-f_{l}(x)}{f_{l}\left(x^{*}\right)}\right]^{p}
$$

dimana,

$$
f_{l}(x) \quad=\text { fungsi tujuan } l
$$

$f_{l}\left(x^{*}\right)=$ Nilai optimal fungsi objektif $l$ (solusi fungsi ideal)

$$
p \quad=\text { Bobot terhadap nilai penyimpangan }
$$

\section{DESKRIPSI PERMASALAHAN}

PT X merupakan salah satu pabrik peleburan aluminium terbesar di Asia Tenggara. Untuk melakukan proses produksi dari bahan baku sampai produk jadi, perusahaan membutuhkan kinerja dari mesin-mesin produksi. Sehingga, 
keandalan dari mesin maupun supply tools dalam proses produksi merupakan salah satu faktor penting agar demand dari produk jadi tetap bisa dipenuhi seutuhnya.

Saat spare part tersebut tidak tersedia, maka proses maintenance yang seharusnya dilakukan menjadi tidak dapat dilakukan sampai spare part dari mesin tersebut tersedia. Hal ini dapat mengakibatkan berhentinya proses produksi, yang mengakibatkan demand dari customer tidak bisa terpenuhi. Hal tersebut menunjukkan bahwa pentingnya pengendalian inventory pada spare part.

Banyaknya proporsi permintaan yang tergolong intermittent, lumpy, maupun erratic menyebabkan kebijakan persediaan tidak bisa dilakukan dengan EOQ, maupun perhitungan safety stock pada umumnya karena tidak berdistribusi normal. Jika dilakukan kebijakan tersebut, biaya persediaannya termasuk biaya safety stock akan naik, karena adanya variabilitas yang sangat tinggi diakibatkan karena adanya 0 permintaan pada beberapa periode.

Pemesanan spare part yang dilakukan secara independen pada PT X menyebabkan tingginya ordering cost. Padahal, proses tender pada spare part tidak terlalu signifikan berpengaruh, karena harus melakukan pembelian item yang banyak jenisnya dan penawaran dilihat berdasarkan kesesuaian spesifikasi part. Jadi, saat ada item dengan supplier yang sama, sementara kebutuhannya pada periode yang berbeda, item - item tersebut akan dipesan secara independen pada periode dimana item tersebut dibutuhkan. Berikut merupakan contoh data yang akan digunakan.

Tabel 1.

Data Permintaan, Volume, dan Persediaan Awal Data Uji 1

\begin{tabular}{ccccccc}
\hline \hline Material Number & Vendor & $\begin{array}{c}\text { Initial } \\
\text { Inventory }\end{array}$ & $\begin{array}{c}\text { Volume } \\
\left(\mathrm{cm}^{3}\right)\end{array}$ & \multicolumn{4}{c}{ Demand } & $t 2$ & $t 3$ \\
\hline $\mathrm{A} 822$ & $\mathrm{AD} 2$ & 0 & 443.7 & 0 & 1 & 0 \\
$\mathrm{~A} 823$ & $\mathrm{AD} 2$ & 1 & 1841.508 & 1 & 0 & 3 \\
$\mathrm{~A} 075$ & $\mathrm{AD} 2$ & 6 & 116.28 & 8 & 4 & 4 \\
\hline \hline
\end{tabular}

Tabel 2.

Data Biaya Persediaan Data Uji 1

\begin{tabular}{cccccc}
\hline \hline $\begin{array}{c}\text { Material } \\
\text { Number }\end{array}$ & Harga & $\begin{array}{c}\text { Holding } \\
\text { Cost }\end{array}$ & $\begin{array}{c}\text { Ordering } \\
\text { Cost }\end{array}$ & $\begin{array}{c}\text { Backordering } \\
\text { Cost }\end{array}$ \\
\hline A822 & $\$ 323.42$ & $\$ 33.96$ & $\$ 25.70$ & $\$ 371.93$ \\
A823 & $\$ 272.13$ & $\$ 28.57$ & $\$ 24.67$ & $\$ 312.95$ \\
A075 & $\$ 516.24$ & $\$ 54.21$ & $\$ 29.56$ & $\$ 774.36$ \\
\hline \hline
\end{tabular}

\section{PENGEMBANGAN MODEL DAN ALGORITMA}

\section{A. Model Matematis}

Berikut merupakan model matematis yang dikembangkan dari model yang telah dibangun oleh Nagasawa [3] pada permasalahan multiple can-order level:

$$
\begin{aligned}
& \text { - Parameter: } \\
& \mathrm{i} \quad=\text { jenis item } \\
& \mathrm{j} \quad=\text { jenis correlated item } \quad(\mathrm{j} \in \mathrm{J}) \\
& \mathrm{t} \quad=\text { waktu perencanaan }(\mathrm{t} \in \mathrm{T}) \\
& \mathrm{M}=\text { big-M } \\
& d_{i t}=\text { demand item } \mathrm{i} \text { pada periode ke } \mathrm{t} \\
& v_{i} \quad=\text { volume item } \mathrm{i} \\
& p_{i} \quad=\text { harga item } \mathrm{i} \\
& C h_{i}=\text { holding cost item } \mathrm{i} \\
& \mathrm{Co}_{i}=\text { orderring cost item } \mathrm{i} \\
& C b_{i}=\text { back-orderring cost item } \mathrm{i} \\
& b \quad=\text { kapasitas angkut } \\
& G=\text { storage capacity }
\end{aligned}
$$

- Variabel Keputusan:

$y_{t} \quad=$ jumlah angkutan pada periode ke $\mathrm{t}$

$s_{i} \quad=$ re-order level item $\mathrm{i}$

$c_{i j}=$ can-order level item $\mathrm{j}$ ketika item $\mathrm{i}$ dipesan

$S_{i j} \quad=$ order-up-to level item $\mathrm{j}$ ketika item $\mathrm{i}$ dipesan

$o_{i t} \quad=$ jumlah item $\mathrm{i}$ yang stockout pada periode $\mathrm{t}$

$I_{i t} \quad$ inventory level item $\mathrm{i}$ pada periode $\mathrm{t}$

$x_{i t}=$ jumlah order quantity item $\mathrm{i}$ pada periode $\mathrm{t}$

$r_{i t}=\left\{\begin{array}{l}1, \text { jika } I_{i t} \text { berada di bawah } s_{i} \text { pada periode } t \\ 0, \text { otherwise }\end{array}\right.$

$k_{i j t}=\left\{\begin{array}{l}1, \text { jika } I_{i t} \text { berada di bawah } c_{i j} \text { pada periode } t \\ 0, \text { otherwise }\end{array}\right.$

$q_{i j t}=\left\{\begin{array}{l}1, \text { jika } I_{i t} \text { berada di bawah } c_{i j} \text {, dan } \\ \text { setidaknya } 1 \text { item dipesan pada periode } t \\ \text { dan tambahan pesanan ditempatkan di } S_{i j} \\ 0, \text { otherwise }\end{array}\right.$

- Fungsi Tujuan:

Minimasi Total Carrier:

Min $\quad Z_{1}=\sum_{t=1}^{T} y_{t}$

Minimasi Total Biaya:

Total Biaya $=$ Total Purchasing Cost + Total Holding Cost

+ Total Ordering Cost + Total Backorderring Cost

Min $Z_{2}=\sum_{t=1}^{T} \sum_{i=1}^{I} x_{i t} p_{i}+\sum_{t=1}^{T} \sum_{i=1}^{I} I_{i t} C h_{i}+\sum_{t=1}^{T} \sum_{i=1}^{I} r_{i t} C o_{i}+\sum_{t=1}^{T} \sum_{i=1}^{I} o_{i t} C b_{i}$

- Konstrain:

Keseimbangan persediaan untuk semua item:

$I_{i, t-1}+x_{i t}-I_{i t}+o_{i t}=d_{i t} ; \forall i, \forall t$

Jumlah pesanan item selama periode waktu dibawah kapasitas angkut:

$$
\sum_{i=1}^{I} v_{i} x_{i t} \leq b y_{t} ; \forall t
$$

Jika level persediaan jatuh pada atau di bawah re-order level, maka pesanan akan ditempatkan:

$$
\begin{aligned}
& I_{i, t-1}-d_{i t}+o_{i t}+M r_{i t} \geq s_{i} ; \forall i, \forall t \\
& I_{i, t-1}-d_{i t}+o_{i t}+M\left(1-r_{i t}\right) \leq s_{i} ; \forall i, \forall t
\end{aligned}
$$

Kuantitas pesanan ditentukan dari selisih order-up-to level dan inventory level:

$$
\begin{aligned}
& S_{i i} \leq I_{i, t-1}-d_{i t}+o_{i t}+x_{i t}+M\left(1-r_{i t}\right) ; \forall i, \forall t \\
& S_{i i} \geq I_{i, t-1}-d_{i t}+o_{i t}+x_{i t}-M\left(1-r_{i t}\right) ; \forall i, \forall t
\end{aligned}
$$

Can-order level tidak lebih dari nilai order-up-to level:

$$
S_{i j} \geq c_{i j} ; \forall i, \forall j
$$

Re-order level tidak lebih dari can-order level:

$$
c_{i j} \geq s_{j} ; \forall i, \forall j
$$

Level persediaan dari suatu item apakah berada pada atau di bawah can-order level dari item:

$$
\begin{aligned}
& I_{j, t-1}-d_{j t}+o_{j t}+M k_{i j t} \geq c_{i j} ; \forall i, \forall j, \forall t \\
& \quad I_{j, t-1}-d_{j t}+o_{j t}-M\left(1-k_{i j t}\right) \leq c_{i j} ; \forall i, \forall j, \forall t
\end{aligned}
$$

Ketika level persediaan dari setidaknya satu item berada pada atau di bawah re-order level, pesanan ditempatkan termasuk item yang level persediaannya berada dibawah atau pada can-order level:

$$
\begin{aligned}
& q_{i j t} \leq k_{i j t} ; \forall i, \forall j, \forall t \\
& q_{i j t} \leq r_{i t} ; \forall i, \forall j, \forall t \\
& \sum_{i=1}^{I} q_{i j t} \leq 1 ; \forall i, \forall t
\end{aligned}
$$




$$
c_{i j} k_{i j t} \leq \sum_{i=1}^{I} c_{i j} q_{i j t} ; \forall i, \forall j, \forall t
$$

Kuantitas item yang dipesan sebesar selisih dari level persediaan dan order-up-to level yang memiliki hubungan dengan item lain terkorelasi:

$$
\begin{aligned}
& S_{i j} \leq I_{j, t-1}-d_{j t}+o_{j t}+x_{j t}+M\left(1-q_{i j t}\right) ; \forall i, \forall j, \forall t \\
& S_{i j} \geq I_{j, t-1}-d_{j t}+o_{j t}+x_{j t}-M\left(1-q_{i j t}\right) ; \forall i, \forall j, \forall t
\end{aligned}
$$

Item dengan level persediaan berada pada atau di bawah can-order dan re-order level bisa dilakukan pemesanan:

$$
x_{j t} \leq M\left(r_{j t}+\sum_{i=1}^{I} q_{i j t}\right) ; \forall j, \forall t
$$

Jumlah item yang shortage pada setiap item tidak lebih dari permintaan:

$$
o_{i t} \leq d_{i t} ; \forall i, \forall t
$$

Jumlah item yang dipesan pada suatu periode tidak melebihi kapasitas penyimpanan:

$$
\sum_{i=1}^{I} x_{i t} \leq G ; \forall t
$$

Konstrain variabel biner dan non-negativity

$$
\begin{aligned}
& r_{i t}, k_{i j t}, q_{i j t}=\{0,1\} ; \forall i, \forall j, \forall t \\
& y_{t}, I_{i t}, x_{i t}, o_{i t}, s_{i}, c_{i j}, S_{i j} \geq 0 ; \forall i, \forall t
\end{aligned}
$$

\section{B. Pengembangan Algoritma Simulated Annealing}

Pengembangan algoritma didasarkan pada model konseptual yang telah dibuat. Berikut ini adalah penjelasan langkah-langkah yang terdapat dalam algoritma SA yang digunakan:

Langkah 1: Inisialisasi

Parameter algoritma SA yang digunakan untuk menyelesaikan contoh kasus ini adalah faktor pereduksi temperatur (cr) dan jumlah siklus (n).

Langkah 2: Pembangkitan Solusi

Di dalam algoritma simulated annealing, solusi dibangkitkan secara random. Solusi awal yang digunakan terdiri dari beberapa variabel seperti, re-order level $\left(\mathrm{s}_{\mathrm{i}}\right)$, canorder level $\left(\mathrm{c}_{\mathrm{ij}}\right)$, order-up-to level $\left(\mathrm{S}_{\mathrm{ij}}\right)$, dan jumlah item yang shortage $\left(\mathrm{o}_{\mathrm{it}}\right)$.

\section{Langkah 3: Perhitungan Fungsi Tujuan}

Pada penyelesaian permasalahan multi tujuan, model akan menyelesaiakan kedua problem fungsi tujuan 1 dan fungsi tujuan 2 terlebih dahulu. Kemudian, model dilakukan running kembali dengan fungsi multi tujuan menggunakan metode global kriteria seperti pada Persamaan (1).

\section{Langkah 4: Pembangkitan Solusi Baru}

Initial solution yang telah dibangkitkan akan diubah menjadi nilai terdekatnya atau biasa disebut neighborhood search sebagai solusi baru. Perubahan solusi yang telah dibangkitkan dilakukan dengan cara melakukan kombinasi perubahan penambahan 1 satuan, pengurangan 1 satuan, atau tidak dilakukan perubahan (bertambah 0 satuan) pada variabel $s, c, S$.

Langkah 5: Membandingkan Solusi Lama dengan Solusi Baru

Setelah mendapatkan solusi baru kemudian dilakukan perhitungan $\Delta f$ yang merupakan selisih antara fungsi tujuan yang didapatkan dengan solusi baru dan solusi yang lama. Jika nilai $\Delta f$ negative maka solusi yang baru lebih baik dibandingkan dengan solusi yang sebelumnya sehingga solusi baru akan diterima. Tetapi, jika solusi baru tidak lebih baik dibandingkan dengan solusi yang lama, maka akan dilakukan perhitungan kriteria metropolis untuk menentukan apakah solusi yang beru diterima atau tidak.

Langkah 6: Update Iterasi, Siklus dan Temperatur

Setelah mencapai jumlah siklus $\mathrm{n}$, temperatur akan direduksi dengan menggunakan faktor pereduksi temperatur (cr). Selain itu, setelah mencapai jumlah siklus n, nilai siklus kembali ditetapkan menjadi sama dengan satu.

Langkah 7: Stopping Criteria

Dalam penelitian ini stopping criteria yang digunakan adalah nilai temperatur yang mendekati 0 .

\section{Verifikasi dan Validasi}

Verifikasi model eksak dilakukan dengan melakuakan evaluasi struktur model yang digenerate dalam software LINGO. Evaluasi model didasarkan pada apakah model yang digenerate telah memiliki struktur yang sesuai dengan model matematisnya.

Dari hasil perhitungan model multi obyektif, hasilnya telah sama dengan perhitungan eksak. Tetapi, untuk

\begin{tabular}{|c|c|c|c|c|c|c|c|}
\hline \multirow{2}{*}{\multicolumn{2}{|c|}{$\begin{array}{l}\text { Fungsi } \\
\text { Tujuan }\end{array}$}} & \multicolumn{3}{|c|}{ N Nilai Solusi } & \multicolumn{3}{|c|}{ Waktu Komputasi (detik) } \\
\hline & & Eksak & SA & $\begin{array}{c}\text { Gap } \\
\%\end{array}$ & $\begin{array}{c}\text { Eksa } \\
\mathrm{k}\end{array}$ & SA & Gap\% \\
\hline \multirow{3}{*}{$\begin{array}{l}\text { Single } \\
\text { Objekti } \\
\text { f }\end{array}$} & Z & 1 & 1 & $0.0 \%$ & 3 & 19. & 560.00 \\
\hline & $\begin{array}{l}\mathrm{I} \\
\mathrm{Z}\end{array}$ & 6441.2 & 6441.2 & & & $\begin{array}{c}8 \\
23 .\end{array}$ & \\
\hline & 2 & 5 & 5 & $0.0 \%$ & 18 & 6 & $31.11 \%$ \\
\hline \multirow{2}{*}{$\begin{array}{l}\text { Multi } \\
\text { Objekti } \\
\text { f }\end{array}$} & $\begin{array}{l}Z \\
1\end{array}$ & 1 & 1 & $0.0 \%$ & 870 & $\begin{array}{c}40 . \\
8\end{array}$ & $-95.31 \%$ \\
\hline & $\begin{array}{l}Z \\
2\end{array}$ & $\begin{array}{c}7187.6 \\
3\end{array}$ & $\begin{array}{c}7187.6 \\
3\end{array}$ & $0.0 \%$ & 870 & $\begin{array}{c}40 . \\
8\end{array}$ & $-95.31 \%$ \\
\hline
\end{tabular}
mencapai hasil yang sama dibutuhkan replikasi dengan jumlah yang besar. Berikut merupakan rekapitulasi hasil verifikasi dan validasi menggunakan data 3 item dan 3 periode.

Tabel 3.

Perbandingan Hasil Verifikasi SA dengan Perhitungan Eksak pada Data Uji 1

Jika dilihat pada nilai solusi, perhitungan SA tidak memiliki perbedaan yang signifikan pada perhitungan eksak. Perbedaan terjadi saat dilakukan running model multi tujuan. Hal ini terjadi karena pada SA dibangkitkan bilangan random yang kemudian akan diperbaiki dengan mencari variabel keputusan berdasarkan Neighborhood Search. Sedangkan, jika dilihat pada waktu komputasi, Algoritma SA pada model single obyektif memiliki waktu yang lebih lama dari pada perhitungan eksak. Tetapi, bila dibandingkan dengan model multi obyektif, Algoritma SA lebih cepat dari pada perhitungan eksak. Hal ini dikarenakan terdapat fungsi non-linear pada fungsi multi objective multi tujuan.

Setelah model dengan 1 supplier dengan 3 item dan 3 periode telah valid, model akan dicoba running kembali

\begin{tabular}{|c|c|c|c|c|c|c|c|}
\hline \multirow{2}{*}{\multicolumn{2}{|c|}{$\begin{array}{l}\text { Fungsi } \\
\text { Tujuan }\end{array}$}} & \multicolumn{3}{|c|}{ Nilai Solusi } & \multicolumn{3}{|c|}{ Waktu Komputasi (detik) } \\
\hline & & Eksak & SA & $\begin{array}{c}\text { GAP } \\
\%\end{array}$ & $\begin{array}{c}\text { Eksa } \\
\mathrm{k}\end{array}$ & SA & GAP $\%$ \\
\hline \multirow{2}{*}{$\begin{array}{l}\text { Single } \\
\text { Objekti } \\
\text { f }\end{array}$} & $\mathrm{Z}$ & 1 & 1 & $0.00 \%$ & 4 & $\begin{array}{c}36.1 \\
4\end{array}$ & $\begin{array}{c}803.5 \\
\%\end{array}$ \\
\hline & $\begin{array}{l}Z \\
2\end{array}$ & $\begin{array}{c}8788.6 \\
1\end{array}$ & $\begin{array}{c}8788.6 \\
1\end{array}$ & $0.00 \%$ & 49 & $\begin{array}{c}38.1 \\
5\end{array}$ & $-22.1 \%$ \\
\hline
\end{tabular}
menggunakan permasalahan multi supplier dengan ukuran 2 supplier dengan 3 item dari supplier 1 dan 2 item dari supplier 2 dengan 3 periode. Berikut merupakan rekapan hasil pada permasalahan kedua.

Tabel 4.

Perbandingan Hasil Verifikasi SA dengan Perhitungan Eksak pada Data Uji 2 


\begin{tabular}{lccccccc} 
& $\mathrm{Z}$ & 1 & 1 & $0.00 \%$ & 445 & 273 & $-38.7 \%$ \\
Multi & 1 & & & & & & \\
Objekti & $\mathrm{Z}$ & 9644.3 & 10371 & $7.53 \%$ & 445 & 273 & $-38.7 \%$ \\
$\mathrm{f}$ & 2 & 2 & & & & & \\
\hline
\end{tabular}

Pada permasalahan multi supplier, didapatkan hasil solusi dengan perbedaan terbesar pada model multi obyektif fungsi tujuan biaya, yaitu sebesar $7.53 \%$. Dari hasil tersebut, algoritma Simulated Annealing dapat dikatakan telah valid, mengacu pada hasil solusinya. Dengan demikian, model yang telah dibangun dapat dilanjutkan untuk permasalahan dengan ukuran yang lebih besar atau pada permasalahan nyata

\section{EKSPERIMEN DAN ANALISA}

Eksperimen dilakukan dengan menggunakan software MATLAB dan LINGO. Software MATLAB digunakan untuk menyelesaikan permasalahan dengan menggunakan algoritma simulated annealing. Spesifikasi komputer yang digunakan adalah Intel ${ }^{\circledR}$ Core $^{\mathrm{TM}}$ i5-4570 3.20 G.Hz (CPU), RAM 8 GB.

\section{A. Eksperimen Uji Parameter}

Dalam algoritma SA terdapat beberapa parameter yang digunakan untuk mengenerate solusi diantaranya adalah cr (faktor pereduksi temperatur) dan $\mathrm{n}$ (banyaknya siklus). Nilai parameter-parameter ini akan mempengaruhi kualitas dan kecepatan dalam men-generate solusi sehingga perlu dilakukan uji parameter untuk menentukan nilai parameter yang tepat untuk mendapatkan solusi yang terbaik. Nilai cr yang diuji adalah 0.9 dan 0,6 . Sedangkan nilai maksimum iterasi tiap siklus yang diuji adalah 100 dan 1000 .

Untuk melakukan pengujian parameter algoritma simulated annealing, data yang digunakan setiap data uji akan digunakan dengan jumlah item, periode, dan supplier yang berbeda. Berikut merupakan ukuran data yang akan digunakan dalam eksperiman uji parameter.

Tabel 5.

Ukuran Data Uji

\begin{tabular}{lccccc}
\hline \hline \multicolumn{1}{c}{ Data } & Produk & Periode & Supplier & Variabel & Konstrain \\
\hline Data Uji 1 & 3 & 3 & 1 & 163 & 304 \\
Data Uji 2 & 5 & 3 & 2 & 363 & 452 \\
Data Uji 3 & 10 & 12 & 3 & 3482 & 4046 \\
Data Studi & 157 & 12 & 3 & $49.455++$ & $57.000++$ \\
Kasus & & & & & \\
\hline \hline
\end{tabular}

Data - data tersebut diambil dari data studi kasus spare part inventory PT $\mathrm{X}$ melalui sampel dengan memperhitungkan item dan supplier yang paling berkontribusi atau memiliki nilai yang tertinggi dari keseluruhan proses pengendalian persediaan. Berikut merupakan hasil perhitungan eksak dari data uji 1, 2, dan 3.

Tabel 6.

Hasil Perhitungan Eksak Setiap Data Uji

\begin{tabular}{llll}
\hline \hline Hasil & Data Uji 1 & Data Uji 2 & Data Uji 3* \\
\hline Jumlah Carrier (unit) & 1 & 2 & 37 \\
Total Biaya (\$) & 7187.63 & 9644.32 & 276464.2 \\
Fungsi Multi objective & 0.013 & 0.009 & - \\
Waktu Komputasi (detik) & 870 & 445 & 68965 \\
Iterasi & 3578609 & 978242 & 15100856 \\
\hline \hline
\end{tabular}

*Hasil Lokal Optimal

Dari uji parameter dengan data uji 1,2, dan 3, didapatkan input parameter yang optimal dengan nilai pereduksi temperatur sebesar 0.6 dan jumlah iterasi tiap siklus sebanyak 1000 iterasi. Setelah didapatkan parameter yang mendapatkan solusi paling baik, setiap data uji akan dilakukan eksperimen kembali dengan melihat perbedaan solusi yang terjadi jika dibandingkan solusi optimalnya dari 10 replikasi. Berikut merupakan hasil 10 replikasi pada data uji 2.

Tabel 7.

Hasil Eksperimen Data Uji 2

\begin{tabular}{|c|c|c|c|c|c|c|c|c|}
\hline \multirow{2}{*}{ 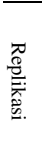 } & \multicolumn{2}{|c|}{$\begin{array}{l}\text { Jumlah Carrier } \\
\text { (unit) }\end{array}$} & \multicolumn{2}{|c|}{ Total Biaya (\$) } & \multicolumn{2}{|c|}{ Multi objective } & \multicolumn{2}{|c|}{$\begin{array}{c}\text { Waktu } \\
\text { Komputasi } \\
\text { (detik) }\end{array}$} \\
\hline & Nilai & & Nilai & Gap\% & Nilai & Gap $\%$ & Nilai & Gap\% \\
\hline 1 & 2 & & & & & & 40.7 & \\
\hline 2 & 2 & & & & & & 0.1 & \\
\hline 3 & 3 & 50.0 & 8838 & $-8.4 \%$ & 0.25 & 2537 & 41.7 & -90.6 \\
\hline 4 & 3 & $\%$ & 8838 & & 0.25 & $40 \%$ & 40.7 & -90. \\
\hline 5 & 2 & & 9644. & & 0.009 & & 40.8 & -90.8 \\
\hline 6 & 2 & 0 & 10542 & & 0.04 & 319 & 40.9 & -90.8 \\
\hline 7 & 2 & $0.00 \%$ & 9644.32 & $0.00 \%$ & 0.009 & $0.00 \%$ & 41 & $-90.80 \%$ \\
\hline 8 & 2 & $0.00 \%$ & 9644.32 & $0.00 \%$ & 0.009 & & 41.1 & $-90.80 \%$ \\
\hline 9 & 3 & & 8838.4 & $-8.4 \%$ & 0.25 & $2537.40 \%$ & 41.2 & $-90.70 \%$ \\
\hline 10 & 2 & $0.00 \%$ & 9644.32 & $0.00 \%$ & 0.009 & $0.00 \%$ & 40.9 & $-90.80 \%$ \\
\hline
\end{tabular}

Berikut hasil rata-rata gap atau perbedaan hasil terhadap perhitungan eksak dari setiap data uji.

Tabel 8.

Rata-Rata Perbedaan Hasil Algoritma SA dengan Perhitungan Eksak

\begin{tabular}{cccc}
\hline \hline \multirow{2}{*}{ Data } & \multicolumn{3}{c}{ Rata- Rata Gap \% } \\
& Carrier & Biaya & Waktu \\
\hline Data Uji 1 & $0.00 \%$ & $2.04 \%$ & $-95.30 \%$ \\
Data Uji 2 & $15.00 \%$ & $-1.59 \%$ & $-90.81 \%$ \\
Data Uji 3 & $-14.60 \%$ & $-61.20 \%$ & $-93.70 \%$ \\
\hline \hline
\end{tabular}

\section{B. Eksperimen Penyelesaian Studi Kasus}

PT X saat ini menerapkan kebijakan persediaan $(s, T)$ dengan $s$ merupakan re-order level dan $T$ adalah replenishment period. Saat persediaan menyentuh atau dibawah re-order level, yang ditetapkan perusahaan sebesar safety stock, perusahaan akan melakukan pemesanan item sebanyak permintaan selama 3 bulan kedepan dari periode dimana level persediaan dibawah re-order level. Dari 157 item yang disuplai 3 supplier, total biaya yang didapat sebesar \$586.185,59 dan total carrier supplier sebanyak 76 unit.

Setelah didapatkan parameter yang menghasilkan solusi terbaik atau lebih cepat konvergen, algoritma SA dicoba untuk menyelesaikan permasalahan riil pada data studi kasus spare part inventory PT X. Berikut merupakan hasil yang didapatkan dari algoritma SA dengan parameter pereduksi temperatur sebesar 0.6 dan maksimum iterasi siklus sebesar 1000 .

Tabel 9.

Hasil Running Algoritma SA pada Penyelesaian Studi Kasus

\begin{tabular}{cccc}
\hline \hline $\begin{array}{c}\text { Replika } \\
\text { si }\end{array}$ & $\begin{array}{c}\text { Jumlah Carrier } \\
(\text { unit })\end{array}$ & $\begin{array}{c}\text { Total Biaya } \\
(\$)\end{array}$ & $\begin{array}{c}\text { Waktu Komputasi } \\
(\text { detik })\end{array}$ \\
\hline 1 & 74 & 512,920 & $37,031.3$ \\
2 & 76 & 545,650 & $37,031.3$ \\
3 & 74 & 501,610 & $19,345.7$ \\
4 & 81 & 705,110 & $16,634.0$ \\
5 & 77 & 739,400 & $21,635.0$ \\
6 & 79 & 596,350 & $32,117.0$ \\
7 & 72 & 645,290 & $36,708.0$ \\
8 & 74 & 512,920 & $37,031.3$ \\
9 & 76 & 545,650 & $37,031.3$ \\
10 & 72 & 645,290 & $36,708.0$ \\
Rata- & 75.5 & 595019 & $31,127.3$ \\
\hline \hline
\end{tabular}


rata

Dari hasil tersebut dapat diketahui dari 74 carrier, 44 diantaranya merupakan carrier dari supplier CI10, serta

\section{Analisa dan Hasil}

Pada kondisi eksisting perusahaan menerapkan kebijakan re-order level sebesar safety stock dengan jumlah pemesanan sebesar kumulatif permintaan selama 3 bulan kedepan. Pemesanan spare part yang dilakukan secara independen pada PT X menyebabkan tingginya ordering cost.

Hal ini menyebabkan jumlah carrier yang diantarkan supplier menjadi tinggi karena bila pemesanan yang dilakukan berbeda periodenya. Dari hasil perhitungan, total biaya yang dikeluarkan perusahaan sebesar $\$ 586,185.59$ dan total jumlah carrier supplier sebesar 76 unit.

Eksperimen yang dilakukan pada algoritma SA, didapatkan parameter terbaik sebesar 1000 maksimum siklus dan 0.6 pereduksi temperatur. Jika dilihat pada hasil tiap parameter, semakin lama waktu komputasi atau semakin besar jumlah iterasi, solusi yang didapatkan bisa jauh lebih optimal. Pada data uji 1 dan 2, solusi yang dihasilkan lebih mudah mencapai nilai optimalnya karena ukuran data yang kecil. Tetapi saat dicoba dengan ukuran data yang lebih besar pada data uji 3, hasil setiap replikasi bisa jauh berbeda. Bahkan, saat dilakukan eksperiman menggunakan metode eksak, hasilnya tidak bisa mencapai nilai optimalnya karena keterbatasan memory dan waktu. Jika bisa dilakukan lebih banyak iterasi lagi, bisa jadi model yang dibangun dapat mendapatkan solusi terbaiknya.

Setelah dilakukan perhitungan kondisi eksisting dan model optimasi, didapatkan hasil perbaikan seperti pada tabel berikut ini.

Tabel 10.

Perbandingan Jumlah Carrier Kondisi Eksisting dan Hasil Optimasi

\begin{tabular}{lccc}
\hline \multirow{2}{*}{ Supplier } & \multicolumn{2}{c}{ Carrier (unit) } & \\
\cline { 2 - 3 } & $\begin{array}{c}\text { Kondisi } \\
\text { Eksisting }\end{array}$ & Hasil Optimasi & Saving \% \\
\hline AD2 & 13 & 14 & $-0.08 \%$ \\
CI10 & 41 & 44 & $-0.07 \%$ \\
GE16 & 22 & 16 & $27.27 \%$ \\
Total & $\mathbf{7 6}$ & $\mathbf{7 4}$ & $\mathbf{2 . 6 3 \%}$ \\
\hline \hline
\end{tabular}

Perbedaan ini terjadi karena adanya perbedaan kebijakan mengenai re-order level dan jumlah pemesanan atau orderup-to level. Pada kondisi eksisting, terdapat beberapa item yang re-order level-nya lebih besar jika dibandingkan dengan hasil perbaikan.

Tabel 11.

Perbandingan Biaya Kondisi Eksisting dan Hasil Optimasi

\begin{tabular}{lccccc}
\hline \hline \multirow{2}{*}{ Komponen Biaya } & \multicolumn{3}{c}{ Biaya (\$) } & \multirow{2}{*}{$\begin{array}{c}\text { Saving } \\
\%\end{array}$} \\
\cline { 2 - 5 } & & $\begin{array}{c}\text { Kondisi } \\
\text { Eksisting }\end{array}$ & Hasil Optimasi & \\
\hline Biaya Pemesanan & $\$$ & $20,756.84$ & $\$$ & $4,994.80$ & $75.94 \%$ \\
Biaya Pembelian & $\$$ & $406,771.11$ & $\$$ & $358,750.00$ & $11.81 \%$ \\
Biaya Penyimpanan & $\$$ & $158,657.64$ & $\$$ & $140,870.00$ & $11.21 \%$ \\
Total Biaya & $\$ 586,185.59$ & $\$ 504,614.80$ & $14.43 \%$ \\
\hline \hline
\end{tabular}

biaya terendah terletak pada biaya pemesanan. Sedangkan pada biaya backorder nilainya sebesar $\$ 0$, karena tidak terjadi shortage. Hasil ini kemudian akan dibandingkan dengan kondisi eksisting yang diterapkan perusahaan.

Jika dilihat dari komponen setiap biaya, perubahan yang signifikan terjadi pada biaya pemesanan yaitu menurun sebesar $75.94 \%$, hal ini terjadi karena pada model multiple can-order level yang dibangun memungkinkan terjadinya penyatuan pesanan pada setiap kelompok item yang memiliki kesamaan supplier.

Sedangkan pada total harga item dan biaya penyimpanan menurun sebesar $11.81 \%$ dan $11.21 \%$. Penurunan biaya pembelian terjadi karena adanya perbedaan jumlah pesanan antara kondisi eksisting dan hasil perbaikan. Perbedaan kebijakan re-order level dan order quantity menyebabkan jumlah item yang dipesan juga menjadi berbeda. Hal tersebut juga mempengaruhi biaya penyimpanan yang juga menurun. Pada biaya backorder, nilai kondisi eksisting dan optimasi sebesar $\$ 0$.

\section{KESIMPULAN}

Berdasarkan hasil eksperimen yang telah dilakukan, dapat diketahui bahwa algoritma SA yang dibangun dapat menemukan nilai solusi yang mendekati optimum, tetapi sulit mencapai nilai global optimal bila dilakukan running model dengan jumlah data yang besar. Pada eksperimen yang dilakukan, gap yang terjadi antara hasil algortima SA dengan perhitungan eksak masih berselisih jauh. Hal ini terjadi karena saat dilakukan dalam jumlah yang besar, variabel yang dibangkitkan nilainya juga semakin besar dan meningkat secara eksponensial. Sehingga waktu komputasi yang dihasilkan juga menjadi sangat lama.

Berdasarkan eksperimen dengan 3 supplier dam 157 item menggunakan multiple can-order level dengan can-order policy yang dihasilkan algoritma Simulated Annealing, didapatkan hasil yang lebih baik dari kebijakan persediaan di PT X dengan biaya persediaan sebesar \$501,610.00 dan jumlah carrier sebanyak 74 unit. Hasil tersebut menunjukkan adanya penghematan dari kondisi eksisting yang diterapkan perusahaan sebesar 2 unit pada jumlah carrier, dan penghematan biaya $14.43 \%$ atau sebesar $\$ 81,570.79$ (Rp 1,060,420,270).

\section{DAFTAR PUSTAKA}

[1] A. Syntetos and et al, "On the Categorization of Demand Patterns," J Opl Res Soc, vol. 56, pp. 495-503, 2005.

[2] N. Ghorbel, S.-A. Addouche, and A. El-Mhamedi, "Replenishment Policies in Static and Dynamic Spare Part Inventory Control: A Survey," IJEDR, vol. 2, no. 4, 2014.

[3] K. Nagasawa and T. Irohara, "Multiple Can-order Level for Canorder Policies under Carrier Capacity and Correlated Demands," J Jpn Ind Manag. Assoc, vol. 67, pp. 114-123, 2016

[4] I. A. Putra and I. N. Pujawan, "Pengendalian Persediaan Spare Part dengan Menggunakan Can-Ordering Policy Studi Kasus: PT. PJB Unit Pembangkitan Gresik," Surabaya, 2011

[5] J. L. Balintfy, "On A Basic Class of Multi-Item Inventory Problems," Manag. Sci, vol. 10, pp. 287-297, 1964. 